\title{
Seasonal variation of consumption of the species used as fruit source by brown howler monkeys (Alouatta clamitans) in southern Brazil
}

\author{
Gisele Aparecida da Silva Doratti dos Santos ${ }^{1,2}$, Edmilson Bianchini ${ }^{1}$ \& Nelio Roberto dos Reis ${ }^{1}$ \\ ${ }^{1}$ Programa de Pós-graduação em Ciências Biológicas, Departamento de Biologia Animal e Vegetal, \\ Universidade Estadual de Londrina - UEL, CP 6001, CEP 86051-970, Londrina, PR, Brasil \\ ${ }^{2}$ Corresponding author: Gisele Aparecida da Silva Doratti dos Santos, e-mail: gidoratti@hotmail.com
}

SANTOS, G.A.S.D., BIANCHINI, E. \& REIS, N.R. Seasonal variation of consumption of the species used as fruit source by brown howler monkeys (Alouatta clamitans) in southern Brazil. Biota Neotrop. 13(3): http:// www.biotaneotropica.org.br/v13n3/en/abstract?article+bn03513032013

\begin{abstract}
Considering the seasonal variation of fruits availability in seasonal semideciduous forests, this study analyzed whether the richness of fruit species exploited by Alouatta clamitans is higher in the rainy period rather than the dry one. Plant species consumed were investigated by visualization and feces analysis, from July 2005 to June 2006, in a seasonal semideciduous forest fragment in Paraná state, Brazil. Ten species of fruits were consumed during the rainy period and 13 during the dry period: three were consumed exclusively during the rainy period; six exclusively during the dry period; and seven in months that covered both dry and rainy periods. The number of fruit species consumed during the rainy period was considerably lower than the expected richness. Moreover, among fruit species consumed during the rainy period, only four bear fruits mainly in this period of the year, the other species bear fruits in great part of it. Therefore, the selectivity of $A$. clamitans was mainly directed to species capable of providing fruits along the year, prioritizing these species even when other fruit sources are available. Keywords: diet, frugivory, fruiting phenology, guariba, seasonal semideciduous forests.
\end{abstract}

SANTOS, G.A.S.D., BIANCHINI, E. \& REIS, N.R. Variação sazonal do consumo das espécies utilizadas como fonte de frutos pelo bugio-ruivo (Alouatta clamitans) no Sul do Brasil. Biota Neotrop. 13(3): http:// www.biotaneotropica.org.br/v13n3/pt/abstract?article+bn03513032013

Resumo: Em face da variação sazonal na disponibilidade de frutos nas florestas estacionais semideciduais, este trabalho analisou se a riqueza de espécies de frutos exploradas por Alouatta clamitans é maior no período chuvoso do que no seco. As espécies vegetais consumidas foram investigadas por visualização e análise de fezes, entre julho de 2005 e junho de 2006, em um fragmento de floresta estacional semidecidual no estado do Paraná, Brasil. Dez espécies de frutos foram consumidas durante o período chuvoso e 13 durante o período seco: três foram consumidas exclusivamente durante o período chuvoso; seis exclusivamente durante o período seco; e sete em meses que abrangeram tanto o período seco quanto o chuvoso. O número de espécies de frutos consumidas durante o período chuvoso foi consideravelmente menor do que a riqueza esperada. Além disso, entre as espécies de frutos consumidas durante o período chuvoso, apenas quatro apresentam frutos principalmente nesse período do ano, as outras espécies apresentam frutos em grande parte do ano. Assim sendo, a seletividade de A. clamitans foi direcionada principalmente para espécies capazes de fornecer frutos ao longo do ano, priorizando essas espécies mesmo quando outras opções de frutos estão disponíveis.

Palavras-chave: dieta, frugivoria, fenologia da frutificação, guariba, floresta estacional semidecidual. 


\section{Introduction}

The primates of genus Alouatta Lacépède, 1799 (howler monkeys) are the most folivorous in the Neotropics (Strier 1992). Nevertheless, they are characterized as folivorous-frugivorous (Crockett \& Eisenberg 1987), due to an important contribution to their diet of ripe and unripe fruits, besides young and mature leaves. To a lesser extent, they also ingest petioles, buds, flowers, seeds and stems (Neville et al. 1988). Their diet is seasonally variable, with constant consumption of mature leaves, and consumption of fruits, flowers and young leaves according to environmental availability (Bicca-Marques \& Calegaro-Marques 1995, Queiroz 1995). In fact, fruit intake may reach more than half the consumption during the greatest abundance period of this resource (Prates et al. 1990, Aguiar et al. 2003).

Since the resource distribution and supply in forests affect the abundance, displacement (Levey 1994) and reproductive success of many vertebrates (Powlesland et al. 1997), maintaining the resource supply throughout the year is essential to the conservation of these species (Reys et al. 2005, França et al. 2009). The concern with the resources provision must be even higher in fragmented landscapes, such as the northern region of Paraná state, Brazil. Although howlers are known for their ability to persist in both conserved and disturbed conditions, they are negatively affected by high levels of habitat loss, fragmentation and degradation. Patch size appears to be the main factor constraining populations in fragmented habitats, probably because patch size is positively related to food availability, and negatively related to anthropogenic pressures, physiological stress and parasite loads. In general, food availability decreases with patch size, not only due to habitat loss, but also because the density of big trees, plant species richness and howlers' home range size are lower in smaller patches, where howlers' population densities are commonly higher (Arroyo-Rodríguez \& Dias 2010).

Most tropical forest communities, especially those in seasonal environments, display seasonal variation in the presence of young leaves, flowers, and fruits (Van Schaik et al. 1993). In seasonal semideciduous forests in Paraná state the availability of zoochorous fruits is higher during the rainy period in comparison to the dry period (Carmo \& Morellato 2000, Novaes 2007, Perina 2011). Due to the seasonal variation of resource availability, this study aimed to analyze the species' fruiting period and consumption by brown howler monkey, A. clamitans Cabrera, 1940, in a forest fragment in northern Parana state and to test the hypothesis that the richness of fruit-producing species exploited by $A$. clamitans is higher during the rainy period rather than the dry period.

\section{Material and Methods}

The study was conducted in Doralice Farm (23 $16^{\circ} \mathrm{S}$ and $51^{\circ} 03^{\prime} \mathrm{W}$ - farm headquarters) located in the municipality of Ibiporã, Parana state, Brazil. The farm is adjacent to the Tibagi River at 484 $\mathrm{m}$ of altitude. Approximately 100 ha are covered by continuous forest vegetation classified as seasonal semideciduous forest (SoaresSilva et al. 1992), surrounded by pastures, and by palm and soybean cultivation, bordering the Tibagi river on south and east.

The climate is humid subtropical (Köppen climate classification $C f a$ ). The average annual temperature is $21.9{ }^{\circ} \mathrm{C}$ and the average pluvial precipitation is $1570 \mathrm{~mm}$. There is a drop in temperature and precipitation from March to September, characterizing the autumn and winter as a colder and drier period (Soares-Silva et al. 1992), July being the coldest month and February the hottest month (Costa et al. 2011). During dry period 20 to $50 \%$ of the trees drop totally or partially their leaves (Instituto... 1992) and flowers and zoochorous fruits become less available (Carmo \& Morellato 2000, Novaes 2007, Perina 2011).
The fieldwork took place from July 2005 to June 2006, counting with direct observations totalizing 24 hours per month in the autumn and winter and 27 hours in spring and summer, corresponding to two days from sunrise to sunset. The group of $A$. clamitans observed had five individuals at the beginning of the work (one adult male, one subadult male, two adult females and one juvenile I) and three at the end (one adult male and two adult females) (according to age and sex classification proposed by Mendes 1989).

The fruit species consumed were observed directly (visualization) and indirectly (fecal analyzes).

During direct observations the species consumed were recorded ad libitum. Infrutescences, and immature and mature fruits were generically called as "fruits". Plant material was collected, herborized, identified by experts, and deposited in the Herbarium of Universidade Estadual de Londrina - FUEL. The species and name spelling of corresponding authors are in accordance with the species list of Brazil's flora (http://floradobrasil.jbrj.gov.br/).

Indirect observations consisted of feces collection during or after the direct observations or during the animal search. Feces collected were washed in running water over a network mesh of $0.5 \mathrm{~mm}$, placed on absorbent paper to dry and screened with tweezers and magnifying glass, for further seeds identification with the assistance of experts. The difference in the number of species per fecal sample among seasons was compared with the Kruskal-Wallis test, using the BioEstat 4.0 software with significance level of $5 \%$.

Rarefaction curves were generated by EstimateS 9.1.0 software (Colwell 2013), after 100 randomizations on the sampling order with $95 \%$ confidence intervals in order to examine whether the species richness observed was greater than, equal to, or lower than the species richness estimated by nonparametric richness estimators ICE and Chao2.

Information about species fruiting period in the region was gathered from the literature (Barneby 1975, Carmo \& Morellato 2000, Mikich \& Silva 2001, Emmerick 2007, Novaes 2007, Pereira et al. 2007, Perina 2011), and from personal observation during the fieldwork.

\section{Results}

Sixteen plant species were identified as fruit source for $A$. clamitans: eleven were identified through visualization and fecal analyses, whereas five were found only in feces (Table 1). In addition to those, six seed species found in feces could not be identified.

Forty-six fecal samples were collected, of which 15 were collected in the winter, 10 in the spring, 9 in the summer and 12 in the autumn. Seeds were found in $82.6 \%$ of fecal samples; in the remaining fecal samples only vegetable fibers were found. The species number per fecal sample ranged from zero to six, with an average of 1.8 , with no difference among seasons $(H=3.1726, p=0.3658)$.

According to phenology data seven species present fruits all year: Ficus eximia, F. guaranitica, F. insipida, Guarea kunthiana, Cecropia glaziovi, Syagrus romanzoffiana and Euterpe edulis; four mainly in the rainy period (spring and summer): Annona sylvatica, Jacaratia spinosa, Maclura tinctoria and Phytolacca dioica; three mainly in the dry period (autumn and winter): Pereskia aculeata, Ocotea silvestris and Psidium sartorianum; and one in the end of the rainy period and in the early dry period: Hyperbaena domingensis (Table 1). A phenological study of $F$. trigonata has not been found for the region, however, it can be inferred from A. clamitans feeding data that the species presents fruits in the dry period. Considering the main period of fruiting, the same number of species provides fruits in both rainy and dry periods. However, 13 species present fruits in 
at least one month of the rainy period and 15 species present fruits in at least one month of the dry period (Table 1).

Three fruit species were consumed exclusively during the rainy period: A. sylvatica, J. spinosa and P. dioica; six exclusively during the dry period: E. edulis, $P$. aculeata, $O$. silvestris, $P$. sartorianum, $H$. domingensis and $F$. trigonata; and seven in months covering both the dry and the rainy period: F. eximia, F. guaranitica, F. insipida, G. kunthiana, C. glaziovi, S. romanzoffiana and M. tinctoria (Table 1). In total, 10 species were consumed during the rainy period and 13 during the dry period.
The rarefaction curves depicted in Figure 1 reflect the richness of fruit species consumed in rainy and dry periods. The number of fruit species consumed during the dry period was close to that expected by ICE and Chao 2 estimators, whereas the number of fruit species consumed during the rainy period was considerably lower than the estimated richness.

The fruit species consumed in most months were $F$. eximia (whose fruits were consumed in eight months of the year), F. guaranitica and F. insipida (whose fruits were consumed in five months of the year). Most fruit species were consumed only during one or two months.

Table 1. Presence of fruits (light gray) or dispersal (dark gray) for the species with a record in the region, and consumption of fruits by Alouatta clamitans in the forest fragment of Doralice Farm (Ibiporã, Paraná, Brazil) from July/2005 to June/2006, according to the information source (V = visualization; F = feces analysis). R = record in the Herbarium FUEL. Autumn: April, May and June; Winter: July, August and September; Spring: October, November and December; Summer: January, February and March. ${ }^{1}$ Perina (2011); ${ }^{2}$ Mikich \& Silva (2001); ${ }^{3}$ Emmerick (2007); ${ }^{4}$ Pereira et al. (2007).

\begin{tabular}{|c|c|c|c|c|c|c|c|c|c|c|c|c|c|}
\hline \multirow{2}{*}{ Species } & \multirow{2}{*}{$\mathbf{R}$} & \multicolumn{3}{|c|}{ Autumn } & \multicolumn{3}{|c|}{ Winter } & \multicolumn{3}{|c|}{ Spring } & \multicolumn{3}{|c|}{ Summer } \\
\hline & & A & $\mathbf{M}$ & $\mathbf{J}$ & JI & Au & $\mathbf{S}$ & $\mathbf{O}$ & $\mathbf{N}$ & D & $\mathbf{J}$ & $\mathbf{F}$ & $\mathbf{M}$ \\
\hline Ficus eximia Schott $^{3}$ & 41865 & $\mathrm{~F}$ & $\mathrm{~F}$ & - & $\mathrm{V} / \mathrm{F}$ & $\mathrm{V} / \mathrm{F}$ & $\mathrm{F}$ & - & - & $\mathrm{F}$ & $\mathrm{F}$ & - & $\mathrm{V} / \mathrm{F}$ \\
\hline F. guaranitica Chodat $^{4}$ & 41861 & $\mathrm{~V} / \mathrm{F}$ & - & - & - & $\mathrm{V} / \mathrm{F}$ & - & $\mathrm{F}$ & - & - & $\mathrm{V} / \mathrm{F}$ & - & $\mathrm{F}$ \\
\hline F. insipida Willd. ${ }^{3}$ & 41863 & $\mathrm{~F}$ & $\mathrm{~V} / \mathrm{F}$ & $\mathrm{F}$ & $\mathrm{F}$ & - & - & $\mathrm{V} / \mathrm{F}$ & - & - & - & - & - \\
\hline Guarea kunthiana A. Juss. ${ }^{1}$ & 41882 & - & - & - & - & $\mathrm{F}$ & $\mathrm{F}$ & $\mathrm{F}$ & - & - & - & - & - \\
\hline Cecropia glaziovi Snethl. ${ }^{2}$ & 41862 & - & - & V & - & - & - & - & $\mathrm{F}$ & - & - & - & - \\
\hline Syagrus romanzoffiana (Cham.) Glassman ${ }^{1}$ & 41870 & - & $\mathrm{F}$ & $\mathrm{F}$ & - & $\mathrm{F}$ & - & - & - & - & - & - & $\mathrm{F}$ \\
\hline Euterpe edulis Mart. ${ }^{1}$ & 41869 & $\mathrm{~F}$ & - & - & - & - & - & - & - & - & - & - & - \\
\hline Annona sylvatica A.St.-Hil. ${ }^{1}$ & 41221 & - & - & - & - & - & - & - & - & - & - & - & $\mathrm{V} / \mathrm{F}$ \\
\hline Jacaratia spinosa (Aubl.) A. DC. ${ }^{1}$ & 41220 & - & - & - & - & - & - & - & - & - & - & - & $\mathrm{V} / \mathrm{F}$ \\
\hline Maclura tinctoria (L.) D. Don ex Steud ${ }^{2}$ & 41886 & $\mathrm{~F}$ & - & - & - & - & - & - & - & $\mathrm{V} / \mathrm{F}$ & - & - & - \\
\hline Phytolacca dioica L. ${ }^{2}$ & 41880 & - & - & - & - & - & - & - & - & $\mathrm{F}$ & - & - & - \\
\hline Pereskia aculeata Mill. ${ }^{2}$ & 41894 & - & - & $\mathrm{V} / \mathrm{F}$ & - & - & - & - & - & - & - & - & - \\
\hline Ocotea silvestris Vattimo-Gil ${ }^{2}$ & 41887 & - & - & - & $\mathrm{V} / \mathrm{F}$ & $\mathrm{F}$ & - & - & - & - & - & - & - \\
\hline Psidium sartorianum (O. Berg) Nied. & 41889 & - & - & $\mathrm{F}$ & $\mathrm{V} / \mathrm{F}$ & $\mathrm{V} / \mathrm{F}$ & - & - & - & - & - & - & - \\
\hline Hyperbaena domingensis (DC.) Benth. & 41878 & - & - & $\mathrm{F}$ & - & - & - & - & - & - & - & - & - \\
\hline F. trigonata L. & 41864 & - & - & $\mathrm{F}$ & $\mathrm{V}$ & - & - & - & - & - & - & - & - \\
\hline
\end{tabular}

A

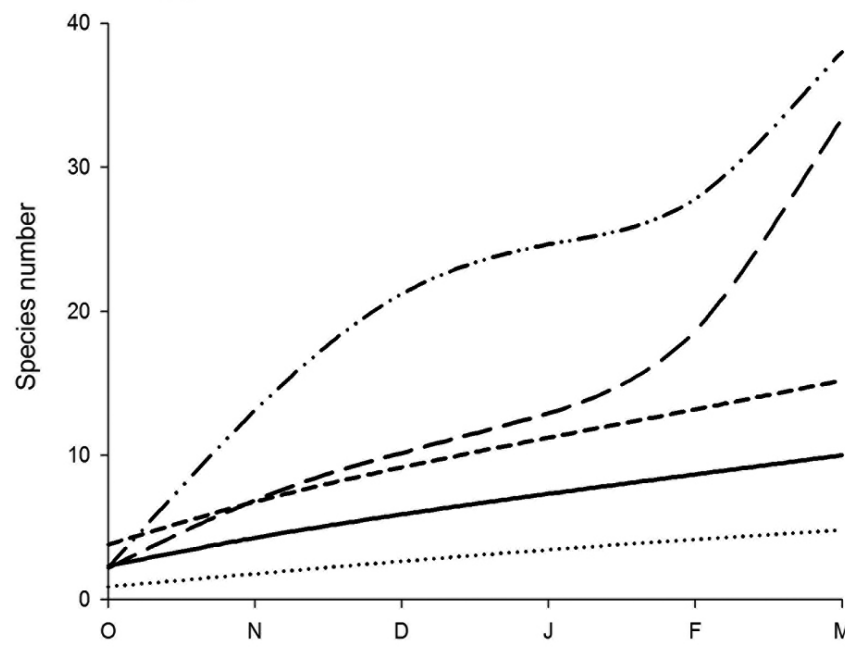

B

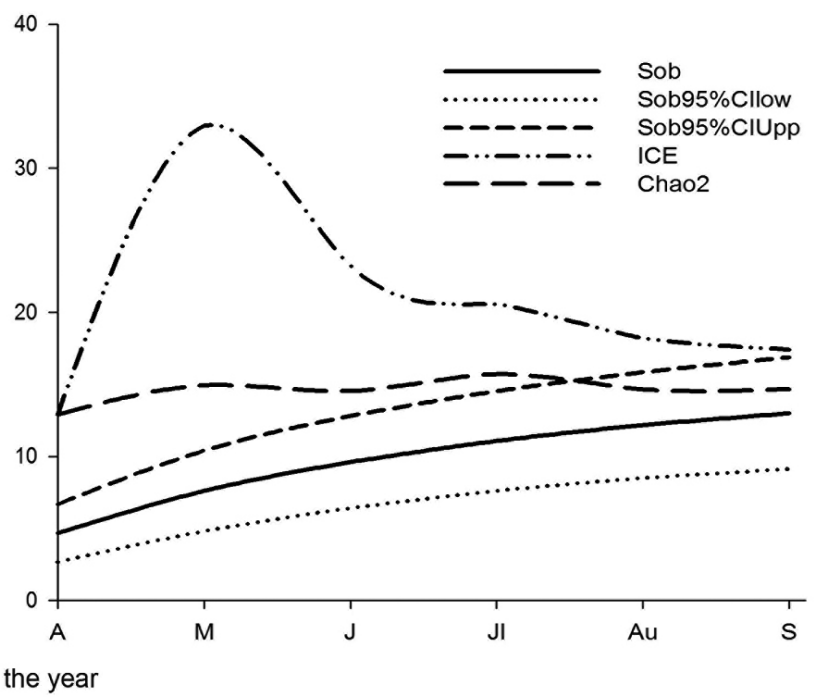

Figure 1. Number of fruit species consumed by Alouatta clamitans in the forest fragment of Doralice Farm (Ibiporã, Paraná, Brazil) from July/2005 to June/2006. Rarefaction curves for species richness observed (Sob) during (A) rainy period (October to March) and (B) dry period (April to September) with 95\% confidence intervals and species richness estimated by nonparametric richness estimators ICE and Chao2. 


\section{Discussion}

Feces collection was extremely important, since one third of fruit sources was exclusively known by this method, in addition to six seed species not identified. Although the sampling effort has remained the same throughout the year, the number of fecal samples collected was lower in the spring and summer because the incidence of rain dismounted the feces. Difference in the number of fecal samples probably did not affect the results because the proportion between species consumed in each period remains the same considering both methods or only species found exclusively in the feces.

Phenology and fruit consumption data show that there is a complementation between the fruiting periods in this community. The studied fragment provides fruits along the year, even during the dry period, when there is typically less resource supply for wildlife. The zoochorous fruits availability along the year is important for nutritional and energetic balance of $A$. clamitans, as well as other animals, especially those predominantly frugivorous that depend on this item to survive. Therefore, the forest fragment of Doralice Farm, though relatively small and having a proportionally large area occupied by edges - due to its elongated shape - preserves important features for wildlife maintenance. This complementation between fruiting periods was observed for the ornithocoric species in seasonal semideciduous forest in the state of São Paulo, although the fruit species consumed by primates Sapajus nigritus (Goldfuss 1809) (capuchin monkey) and A. clamitans showed no marked pattern of sequential fruiting (Galetti 1992).

The fruit consumption of Ficus spp. by A. clamitans during several months of the year was also reported by Prates et al. (1990) and Aguiar et al. (2003), not surprisingly, due to its known intraspecific asynchronous fruiting pattern (Milton 1991, Bicca-Marques 2003, Tweheyo \& Lye 2003, Emmerick 2007). However Ocotea Aubl. (Miranda \& Passos 2004), S. romanzoffiana, and Coussapoa microcarpa (Schott) Rizzini (Prates et al. 1990) were similarly pointed as fruit sources present in the diet of $A$. clamitans most of the year. In southern Amazon rainforest Dialium guianense (Aubl.) Sandwith was the main fruit source for A. discolor (Spix, 1823) (red-handed howler), used during six months of the year (Pinto \& Setz 2004).

The consumption of most fruit species only during one or two months was also reported by Pinto \& Setz (2004) for A. discolor and by Aguiar et al. (2003) for $A$. clamitans.

Although producing fruits during a long period, some species were consumed within a few months. However, it is possible to notice in these cases that consumption occurred mainly during the months when fruits are ripe and ready for dispersal. For instance, $E$. edulis produces fruits almost the whole year, but the fruits were only consumed in April, one of the months in which the species dispersal occurs (Perina 2011); G. kunthiana bears fruits all year, but its fruits were consumed only from August to October, the species dispersal period (Perina 2011); P. dioica bears fruits from August to March, but its fruits were only consumed in December, one of the months in which dispersal occurs (Mikich \& Silva 2001).

According to Carmo \& Morellato (2000), although there are zoochorous species producing ripe fruit along the year in the riparian forests of the Tibagi river, there is a higher number of species fruiting during the rainy period. Therefore, a higher number of fruit species consumed during the spring and summer was expected compared to autumn and winter. Contrary to the expectations, A. clamitans exploited a relatively low number of fruit species during the rainy period. In similar proportions with the present study, Ludwig et al. (2008) reported that most sources of fruits - five species - consumed by black-and-gold howler monkeys, $A$. caraya (Humboldt 1812), in riparian forest in the Upper Paraná River (mainland) were used both in the rainy and dry period, whereas three were consumed exclusively during dry period and one exclusively in the rainy period.

Differently from our findings, Ludwig et al. (2008) studying $A$. caraya in an island in the Upper Paraná river, and Aguiar et al. (2003) studying A. clamitans in Doralice Farm, reported a higher richness of fruit species consumed exclusively during the rainy period, in comparison to species consumed exclusively in the dry period or those consumed in both periods. Prates et al. (1990) studying $A$. clamitans in Parque Estadual de Itapuã, southern Brazil, reported that about a half of fruit species was consumed exclusively during the rainy period, the remaining fruit species were consumed in both periods, and none was consumed exclusively in the dry period. They dismembered the fruit supplying plants into three groups: preferred perennial species - fruit throughout the year and are always consumed; preferred annual species - fruit only during certain times of the year but are widely exploited during these periods; and alternative species - plants with a long-term bearing periods, but from which fruits are eaten only occasionally. Most of the fruit species consumed by the group they studied was "preferred annual species", all fruiting and being consumed in the rainy period. These reports suggest that howlers exploit fruit species available during the dry period but expand fruit sources when there are more options to choose.

Among so many species that bear fruits during the rainy period, why only a few are present on the diet of $A$. clamitans in the forest fragment of Doralice Farm? Many consumers shift food preferences according to their environmental availability. When there is high food availability, consumers tend to focus on high-energy items and on sites with abundance. As a result, they consume fewer food options in greater quantity. In this way, they minimize time and energy spent in searching and maximize energy intake. When there is low food availability, search time is relatively high, leading the consumer to accept a higher number of species as food, even those which are not preferred food resources, rather than ignore them and continue its search for favorite items (Dajoz 2005, Begon et al. 2007). Despite the low number of fruit species consumed in the rainy period, the amount of fruits consumed did not show the same pattern. In the same period of study, summer was the season with the highest rate of fruit consumption and the only season in which time spent on fruit consumption exceeded time spent on leaves consumption (Santos 2007). Hence, the harvest of favorite fruits is probably sufficient during the rainy period, therefore $A$. clamitans does not search for other species; in the dry period, with no preferred fruits in sufficient quantity to supply its nutritional and energetic demands, a higher number of fruit species is exploited.

It is important to remember that howlers are folivorousfrugivorous (Crockett \& Eisenberg 1987) and their diet is seasonally variable, with constant consumption of mature leaves, and consumption of fruits, flowers and young leaves according to environmental availability (Bicca-Marques \& Calegaro-Marques 1995, Queiroz 1995). Thus, in times of low food availability, when consumers tend to accept a higher number of species as food, even lower-quality items, howlers are expected to expand their diet including leaves sources, instead of continuing their search for fruits, which are scarce. The fact that $A$. clamitans expanded fruit sources during the period of low food availability is one more strong indication of the quality of the fragment where it lives.

Among the 10 fruit species consumed during the rainy period, only four bear fruits mainly in this period of the year, the other species bear fruits in great part of it. Even if the trend is the choice of a few species during the period of high food availability, A. clamitans could have selected other fruit species among the large number of options, different from those it uses during times of food scarcity. 
Among so many species that bear fruits mainly during the rainy period, why only a few are chosen to be part of the diet of $A$. clamitans in this time of the year? In the midst of the tree species sampled in the forest fragment of Doralice Farm (Soares-Silva et al. 1992) there are more than 50 zoochorous species, among which about a third was identified as fruit sources for A. clamitans. According to Galetti et al. (2011) monkeys consume fruits of $41 \%$ of the 186 zoochorous species sampled in a lowland Atlantic rain forest of the Parque Estadual Intervales, southeast Brazil. Prates et al. (1990) observed that fruit species used for A. clamitans comprised only $15.3 \%$ of the potential food sources in an adjacent area with the same floristic formation of the Parque Estadual de Itapuã, highlighting its selective diet. The selectivity in the food choice by Alouatta is essential to obtain a nutritionally adequate diet (Nagy \& Milton 1979). Moreover, using a limited number of plant species and individuals as food sources may allow Alouatta to specialize and be more efficient in the use of such resources (Serio-Silva et al. 2002). Differences in chemical and nutritional contents affect the selection of species, individuals, and feed items by Alouatta (Silver et al. 2000, Teaford et al. 2006, Welker et al. 2007, Behie \& Pavelka 2012a, b, Luecke-Bridgeman 2012), but density, abundance and phenological patterns of plant species strongly influence food selection, since the permanent availability of resources offers the chance to use them intensively and meet their basic nutrient needs, rather than use ephemeral, nutrientrich resources (Serio-Silva et al. 2002). It can be inferred that the selectivity of $A$. clamitans was mainly directed to species capable of providing fruits along the year, prioritizing these species even when other fruit sources are available.

According to our findings in the dry period several fruit species collaborated to nutritional and energetic balance of $A$. clamitans, whereas during the rainy period a relatively low number of fruit species was exploited, presumably those which could provide fruits in sufficient quantity to supply its nutritional and energetic demands without spending too much time and energy searching. The phenological patterns of plant species clearly influenced food choice, since A. clamitans prioritized species that bear fruits throughout the year instead species that bear fruits in a short period of the year.

\section{Acknowledgments}

The authors thank CNPq for the scholarship granted to the first author and CAPES for the financial support of the Programa de Pós-graduação em Ciências Biológicas, Universidade Estadual de Londrina; Pedro Favoretto, Doralice Farm's owner, for the permission to work in his property; Dr. Ana Odete Santos Vieira, curator of the Herbarium of Universidade Estadual de Londrina, for plant species identification; Dr. José Marcelo Domingues Torezan and Ms. Alba L. Cavalheiro, for seed identification; Maíra Posteraro Freire and Luciana Festti for the data collection support.

\section{References}

AGUIAR, L.M., REIS, N.R., LUDWIG, G. \& ROCHA, V.J. 2003. Dieta, área de vida, vocalizações e estimativas populacionais de Alouatta guariba em um remanescente florestal no norte do Estado do Paraná. Neotrop. Primates. 11(2):78-85.

ARROYO-RODRÍGUEZ, V. \& DIAS, P.A. 2010. Effects of habitat fragmentation and disturbance on howler monkeys: a review. Am. J. Primatol. 72:1-16. http://dx.doi.org/10.1002/ajp.20753

BARNEBY, R.C. 1975. Menispermáceas. In Flora ilustrada catarinense (R. Reitz, ed.). Herbário Barbosa Rodrigues, Itajaí, p.1-40.

BEGON, M., TOWNSEND, C.R. \& HARPER, J.L. 2007. Ecologia: de indivíduos a ecossistemas. Artmed, Porto Alegre.
BEHIE, A.M. \& PAVELKA, M.S.M. 2012a. Food selection in the black howler monkey following habitat disturbance: implications for the importance of mature leaves. J. Trop. Ecol. 28(2):153-160. http://dx.doi.org/10.1017/ S0266467411000678

BEHIE, A.M. \& PAVELKA, M.S.M. 2012b. The role of minerals in food selection in a black howler monkey (Alouatta pigra) population in Belize following a major hurricane. Am. J. Primatol. 74:1054-1063. http://dx.doi. org/10.1002/ajp.22059

BICCA-MARQUES, J.C. 2003. How do howler monkeys cope with habitat fragmentation? In Primates in fragments: ecology and conservation (L.K. Marsh, ed.). Kluwer Academic/Plenum, New York, p.283-303. http:// dx.doi.org/10.1007/978-1-4757-3770-7_18

BICCA-MARQUES, J.C. \& CALEGARO-MARQUES, C. 1995. Ecologia alimentar do gênero Alouatta Lacépède, 1799 (Primates, Cebidae). Cad. UFAC 3:23-49.

CARMO, M.R.B. \& MORELLATO, L.P.C. 2000. Fenologia de árvores e arbustos das matas ciliares da bacia do rio Tibagi, estado do Paraná, Brasil. In Matas Ciliares: conservação e recuperação (R.R. Rodrigues \& H.F. Leitão Filho, eds.). Editora da Universidade de São Paulo - Fapesp, São Paulo, p.125-141.

COLWELL, R.K. 2013. EstimateS 9.1.0. Department of Ecology \& Evolutionary Biology, University of Connecticut, Storrs. http://viceroy. eeb.uconn.edu/estimates (último acesso em 12/07/2013).

COSTA, J.T., ESTEVAN, D.A., BIANCHINI, E. \& FONSECA, I.C.B. 2011. Composição florística das espécies vasculares e caráter sucessional da flora arbórea de um fragmento de floresta estacional semidecidual no Sul do Brasil. Rev. Brasil. Bot. 34(3):409-420.

CROCKETT, C.M. \& EISENBERG, J.F. 1987. Howlers: variations in group size and demography. In Primates societies (B.B. Smuts, D.L. Cheney, R.M. Seyfarth, R.W. Wrangham \& T.T. Struhsaker, eds.). The University of Chicago Press, Chicago, p.56-68.

DAJOZ, R. 2005. Princípios de ecologia. Artmed, Porto Alegre.

EMMERICK, J.M. 2007. Fenologia de Ficus glabra Vell. e Ficus insipida Willd. no Parque Estadual Mata dos Godoy, Londrina - PR. Dissertação de Mestrado, Universidade Estadual de Londrina, Londrina.

FRANÇA, L.F., RAGUSA-NETTO, J. \& PAIVA, L.V. 2009. Consumo de frutos e abundância de Tucano Toco (Ramphastos toco) em dois hábitats do Pantanal Sul. Biota Neotrop. 9(2):125-130 http://www.biotaneotropica. org.br/v9n2/pt/abstract?article+bn02109022009

GALETTI, M. 1992. Sazonalidade na dieta de vertebrados frugívoros em uma floresta semidecídua no Brasil. Dissertação de Mestrado, Universidade Estadual de Campinas, Campinas.

GALETTI, M., PIZO, M.A. \& MORELLATO, L.P.C. 2011. Diversity of functional traits of fleshy fruits in a species-rich Atlantic rain forest. Biota Neotrop. 11(1):181-194 http://www.biotaneotropica.org.br/v11n1/ en/abstract?article+bn02811012011

INSTITUTO BRASILEIRO DE GEOGRAFIA E ESTATÍSTICA - IBGE. 1992. Manual técnico da vegetação brasileira. DERNA, Rio de Janeiro. Manuais Técnicos de Geociências n.1.

LEVEY, D.J. 1994. Why we should adopt a broader view of neotropical migrants. Auk 111(1):233-236. http://dx.doi.org/10.2307/4088533

LUdWIG, G., AGUiAR, L.M., SVOBODA, W.K., HILST, C.L.S., NAVARRO, I.T., VITULE, J.R.S. \& PASSOS, F.C. 2008. Comparison of the diet of Alouatta caraya (Primates: Atelidae) between a riparian island and mainland on the Upper Parana River, southern Brazil. Rev. Bras. Zool. 25(3):419-426. http://dx.doi.org/10.1590/S0101-81752008000300006

LUECKE-BRIDGEMAN, L. 2012. Diet of the black howler monkey (Alouatta pigra) in mangrove forests and the phytochemistry of mangrove plants. Am. J. Phys. Anthropol. 147:197.

MENDES, S.L. 1989. Estudo ecológico de Alouatta fusca (Primates: Cebidae) na Estação Biológica de Caratinga, MG. Rev. Nordestina Biol. 6(2):71104. 
MIKICH, S.B. \& SILVA, S.M. 2001. Composição florística e fenologia das espécies zoocóricas de remanescentes de floresta estacional semidecidual no centro-oeste do Paraná, Brasil. Acta Bot. Bras. 15(1):89-113. http:// dx.doi.org/10.1590/S0102-33062001000100010

MILTON, K. 1991. Leaf change and fruit production in six Neotropical Moraceae species. J. Ecol. 79:1-26. http://dx.doi.org/10.2307/2260781

MIRANDA, J.M.D. \& PASSOS, F.C. 2004. Hábito alimentar de Alouatta guariba (Humboldt) (Primates, Atelidae) em Floresta de Araucária, Paraná, Brasil. Rev. Bras. Zool. 21(4):821-826. http://dx.doi.org/10.1590/ S0101-81752004000400016

NAGY, K.A. \& MILTON, K. 1979. Aspects of dietary quality, nutrient assimilation and water balance in wild howler monkeys (Alouatta palliata). Oecologia 39(3):249-258.

NEVILLE, M.K., GLANDER, K.E., BRAZA, F. \& RYLANDS, A.B. 1988. The howling monkeys, genus Alouatta. In Ecology and behavior of neotropical primates (R.A. Mittermeier, A.B. Rylands, A. Coimbra-Filho \& G.A.B. Fonseca, eds.). Littera Maciel Ltda, Contagem, p.349-453. http://dx.doi.org/10.1007/BF00345437

NOVAES, T.G. 2007. Fenologia reprodutiva de espécies arbóreas da região de Londrina, PR. Dissertação de Mestrado, Universidade Estadual de Londrina, Londrina.

PEREIRA, R.A.S., RODRIGUES, E. \& MENEZES JR, A.O. 2007. Phenological patterns of Ficus citrifolia (Moraceae) in a seasonal humidsubtropical region in Southern Brazil. Plant Ecol. 188(2):265-275. http:// dx.doi.org/10.1007/s11258-006-9161-0

PERINA, B.B. 2011. Fenologia de espécies arbóreas de uma floresta estacional semidecidual do Sul do Brasil. Dissertação de Mestrado, Universidade Estadual de Londrina, Londrina.

PINTO, L.P. \& SETZ, E.Z.F. 2004. Diet of Alouatta belzebul discolor in an Amazonian Rain Forest of northern Mato Grosso State, Brazil. Int. J. Primatol. 25(6):1197-1211. http://dx.doi.org/10.1023/ B:IJOP.0000043958.75534.7f

POWLESLAND, R.G., DILKS, P.J., FLUX, I.A., GRANT, A.D. \& TISDALL, C.J. 1997. Impact of food abundance, diet and food quality on the breeding of the fruit pigeon, Parea Hemiphaga novaeseelandiae chathamensis, on Chatham Island, New Zealand. Ibis 139(2):353-365. http://dx.doi. org/10.1111/j.1474-919X.1997.tb04634.x

PRATES, J.C., GAYER, S.M.P., KUNZ JUNIOR, L.F. \& BUSS, G. 1990. Feeding habits of the brown howler monkey Alouatta fusca clamitans (Cabrera, 1940) (Cebidae, Alouattinae) in the Itapuã State Park: a preliminary report. Acta Biol. Leopold. 12(1):175-188.
QUEIROZ, H.L. 1995. Preguiças e guaribas: os mamíferos folívoros arborícolas do Mamirauá. Marigo Comunicação Visual, Rio de Janeiro.

REYS, P., GALETTI, M., MORELLATO, L.P.C. \& SABINO, J. 2005. Fenologia reprodutiva e disponibilidade de frutos de espécies arbóreas em mata ciliar no rio formoso, Mato Grosso do Sul. Biota Neotrop. 5(2):1-10 http://www.biotaneotropica.org.br/v5n2/pt/abstract?shortcommunication+bn01205022005

SANTOS, G.A.S.D. 2007. Dieta e dispersão de sementes pelo "bugioruivo", Alouatta clamitans Cabrera, 1940 (Primates, Atelidae), em um fragmento florestal no norte do Paraná, Brasil. Dissertação de Mestrado, Universidade Estadual de Londrina, Londrina.

SILVER, S.C., OSTRO, L.E.T., YEAGER, C.P. \& DIERENFELD, E.S. 2000. Phytochemical and mineral components of foods consumed by black howler monkeys (Alouatta pigra) at two sites in Belize. Zoo Biol. 19(2):95109. http://dx.doi.org/10.1002/1098-2361(2000)19:2\%3C95::AIDZOO1\%3E3.0.CO;2-D

SERIO-SILVA, J.C., RICO-GRAY, V., HERNÁNDEZ-SALAZAR, L.T. \& ESPINOSA-GÓMEZ, R. 2002. The role of Ficus (Moraceae) in the diet and nutrition of a troop of Mexican howler monkeys, Alouatta palliata mexicana, released on an island in southern Veracruz, Mexico. J. Trop. Ecol. 18:913-928.

SOARES-SILVA, L.H., BIANCHINI, E., FONSECA, E.P., DIAS, M.C., MEDRI, M.E. \& ZANGARO-FILHO, W. 1992. Composição florística e fitossociologia do componente arbóreo das florestas ciliares da bacia do rio Tibagi. 1 - Fazenda Doralice - Ibiporã, PR. Rev. Inst. Flor. 4:199-206.

STRIER, K.B. 1992. Atelinae adaptations: behavioral strategies and ecological constraints. Am. J. Phys. Anthropol. 88(4):515-524. http://dx.doi. org/10.1002/ajpa.1330880407

TEAFORD, M.F., LUCAS, P.W., UNGAR, P.S. \& GLANDER, K.E.. 2006. Mechanical defenses in leaves eaten by Costa Rican howling monkeys (Alouatta palliata). Am. J. Phys. Anthropol. 129(1):99-104. http://dx.doi. org/10.1002/ajpa.20225

TWEHEYO, M. \& LYE, K.A. 2003. Phenology of figs in Budongo Forest Uganda and its importance for the chimpanzee diet. Afr. J. Ecol. 41(4):306-316. http://dx.doi.org/10.1111/j.1365-2028.2003.00475.x

VAN SCHAIK, C.P., TERBORGH, J.W. \& WRIGHT, S.J. 1993. The phenology of tropical forests: adaptive significance and consequences for primary consumer. Annu. Rev. Ecol. Syst. 24:353-377. http://dx.doi. org/10.1146/annurev.ecolsys.24.1.353

WELKER, B.J., KÖNIG, W., PIETSCH, M. \& ADAMS, R.P. 2007. Feeding selectivity by mantled howler monkeys (Alouatta palliata) in relation to leaf secondary chemistry in Hymenaea courbaril. J. Chem. Ecol. 33:11861196. http://dx.doi.org/10.1007/s10886-007-9292-3 